\title{
Influence of Bath Temperature on Structural, Optical and Electrical Properties of Cadmium Sulfide Thin Films Prepared by Chemical Bath Deposition
}

\author{
(c) 2019 M. V. Gapanovich ${ }^{1}$, N. A. Tikhonina ${ }^{1}$, T. S. Kokovina ${ }^{2}$, D. N. Varseev ${ }^{1,2}$, V. V. Rakitin ${ }^{1}$, \\ M. Reddivari ${ }^{3}$, P. Babu ${ }^{3}$, K. T. Ramakrishna Reddy ${ }^{3}$, G. F. Novikov ${ }^{\otimes 1,2}$ \\ ${ }^{1}$ Institute of Problems of Chemical Physics of Russian Academy of Sciences \\ 1, Academician Semenov ave., 142432 Chernogolovka, Moscow Region, Russian Federation \\ ${ }^{2}$ Lomonosov Moscow State University, Faculty of Fundamental Physicochemical Engineering \\ 1, Leninskie Gory, GSP-1, 119991 Moscow Russian Federation \\ ${ }^{3}$ S.V. University, Solar Photovoltaic Laboratory, Department of Physics \\ Andhra Pradesh, 517502 Tirupati, India
}

\begin{abstract}
The effect of bath temperature $\left(60-90^{\circ} \mathrm{C}\right)$ on structural, optical and electrical properties of CdS thin films deposited by chemical bath deposition (CBD) at a constant precursor concentration and deposition time was studied. From the XRD analysis, it was found that the structure of CdS thin films varied with temperature. At lower temperature hexagonal structure was dominated while at high temperature, the cubic structure was prominent. The band gap of the as-prepared CdS thin films was calculated from the UV-Vis spectroscopic data, and it was found to be decreased with the increase of temperature. The resistivity of the CdS thin films also decreased with the increase in temperature.
\end{abstract}

Keywords: cadmium sulfide, CBD, temperature effect, structural change, growth mechanism, electrical properties.

\section{INTRODUCTION}

CdS is an n-type semiconductor that belongs to the II-VI group of compounds with a direct band gap of $2.42 \mathrm{eV}$. CdS is a potential material for visible and near-infrared range applications. Particularly, it can be used in solar cells and photodetectors. For photovoltaic application CdS thin films must have appropriate optical absorption, high transparency, high photoconductivity and low film thickness to avoid absorption in the window layer [1]. Now a day's many of the researchers focused on Cadmium Sulphide (CdS) thin films because of excellent properties such as high carrier concentration $\left(10^{16}\right.$ $\left.10^{18} \mathrm{~cm}^{-3}\right)$ and mobility $\left(0.1-10 \mathrm{~cm}^{2} \mathrm{~V}^{-1} \mathrm{~s}^{-1}\right)$, tunable band gap (2.1-2.45 eV), high electrochemical stability and high absorption coefficient $\left(>10^{4} \mathrm{~cm}^{-1}\right)$ compared to bulk CdS counterparts [2]. Cadmium sulfide, in polycrystalline form, provides the best photovoltaic characteristics in CIGS-and CdTebased thin film solar cells, respectively as buffer layer and window layer material. The maximum the-

Gennady F. Novikov, e-mail: gfnovikov@gmail.com oretical limit of photovoltaic conversion efficiency for CIGS and CdTe-based thin film solar cell with one hetero-junction is higher than $30 \%$, but the cell efficiency over $20 \%$ was reached now. There is scope to increase the cell efficiency further $20 \%$ by reducing the thickness of CdS window layer below $100 \mathrm{~nm}$.

One of the most common methods for deposition of CdS layers is the Chemical Bath Deposition (CBD). This method is suitable for deposition of thin films over a larger area. It is also rather simple and cheap. At the same time, it is known that deposition temperature, availability of impurities, qualitative characteristics of substrates, etc. can affect the properties of CdS thin films. The thickness of CdS layer can be controlled by tuning the deposition parameters, particularly, the bath temperature showed greater influence on the film thickness due to changes in the reaction kinetics.

Therefore, the main purpose of this work is to study the influence of deposition temperature on the structural, optical, and electrical properties of CdS thin films deposited by CBD method at 
a constant precursor's concentration and deposition time.

\section{EXPERIMENTAL}

Deposition of CdS thin films

CdS thin films were prepared by using chemical bath deposition method. For the preparation of CdS thin films, the pre-cleaned and dried glass substrates were inserted vertically into the bath containing $0.0029 \mathrm{~mol} / \mathrm{l}$ of $\mathrm{CdSO}_{4}, 0.15$ of mol/l of $\mathrm{CS}\left(\mathrm{NH}_{2}\right)_{2}$ and $1.72 \mathrm{~mol} / \mathrm{l}$ of $\mathrm{NH}_{3} \cdot \mathrm{H}_{2} \mathrm{O}$ and then deposition was carried out at various deposition temperatures in the range of $60-90{ }^{\circ} \mathrm{C}$ at a constant deposition time of $\mathrm{t}=20 \mathrm{~min}$. Fig. 1 shows the arrangement of chemical bath deposition.

\section{Characterization}

The structural properties were analysed using $\mathrm{X}$-ray diffraction (XRD) (with $\mathrm{Cu}-\mathrm{K}_{\alpha}$ radiation, diffractometer ADP-2-01). In view of the low thickness of deposited films (50-200 nanometers), the $\mathrm{XRD}$ analysis is complicated. Therefore, the multiple depositions were carried out under the same conditions described above. The optical band gap of CdS thin films was calculated from the absorbance spectra, measured using Shimadzu UV-Vis 3101PC spectrophotometer in the wavelength range of 200-1700 $\mathrm{nm}$. To determine the electrical resistivity of CdS thin films, indium contacts were deposited by thermal evaporation using an aluminum mask and then the potential sweep was applied to the contacts and the corresponding current was measured.

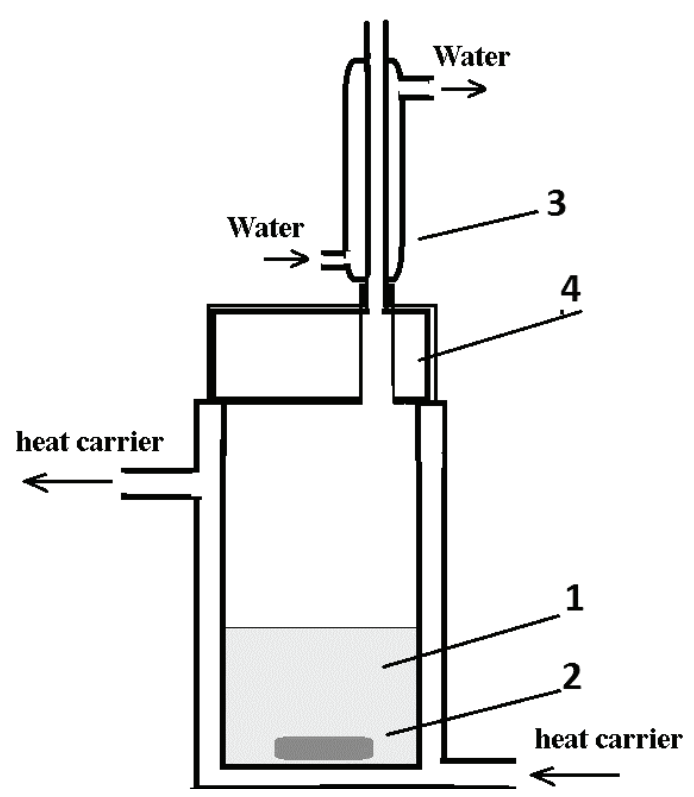

Fig. 1. Schematic of CBD thin film deposition for solar cell preparation

\section{RESULTS AND DISCUSSION}

\section{Growth mechanism of CdS thin films}

In the deposition of CdS thin films, ammonium hydroxide acts as the complex agent and it forms cadmium ammonia complex as shown below:

$$
\mathrm{Cd}^{2+}+4 \mathrm{NH}_{3} \rightarrow \mathrm{Cd}\left(\mathrm{NH}_{3}\right)_{4}{ }^{2+}
$$

The formation of cadmium ammonia complex in solution provides the slow release of cadmium ions. Generally, the growth mechanism of CdS thin film using ammonia can be presented in the following reactions:

$$
\begin{aligned}
& \mathrm{Cd}^{2+}+4 \mathrm{NH}_{3} \leftrightarrow \mathrm{Cd}\left(\mathrm{NH}_{3}\right)_{4}^{2+} \\
& \mathrm{NH}_{3}+\mathrm{H}_{2} \mathrm{O} \leftrightarrow \mathrm{NH}_{4}^{+}+\mathrm{OH}^{-} \\
& \mathrm{Cd}^{2+}+2 \mathrm{OH}^{-} \leftrightarrow \mathrm{Cd}(\mathrm{OH})_{2} \\
& \mathrm{SC}\left(\mathrm{NH}_{2}\right)_{2}+2 \mathrm{OH}^{-} \leftrightarrow \mathrm{S}^{2-}+2 \mathrm{H}_{2} \mathrm{O}+\mathrm{H}_{2} \mathrm{CN}_{2} \\
& \mathrm{Cd}(\mathrm{OH})_{2}+\mathrm{S}^{2-} \leftrightarrow \mathrm{CdS}+2 \mathrm{OH}^{-} .
\end{aligned}
$$

During deposition of CdS thin films, clusters were formed and their size differs depending on deposition temperature.

\section{Deposition temperature versus film thickness}

Fig. 2 shows the dependence of film thickness on the deposition temperature. As shown in Fig. 2, the thickness of film was increased from $30 \mathrm{~nm}$ to $90 \mathrm{~nm}$ when the bath temperature was varied in the range, $60-80^{\circ} \mathrm{C}$ and then it decreased at $90^{\circ} \mathrm{C}$. This is because of the increased growth rate with rise of deposition temperature until the film thickness reached an upper limit, thereafter it decreased. The decrease of film thickness after $80^{\circ} \mathrm{C}$ was due to the dissolution of unstable nuclei adsorbed on the film surface, or after reaching a certain thickness film starts to peel off. A similar type of observation was also reported in literature by few investigators [2-4]. For example, Fangyang et al. [3] ob-

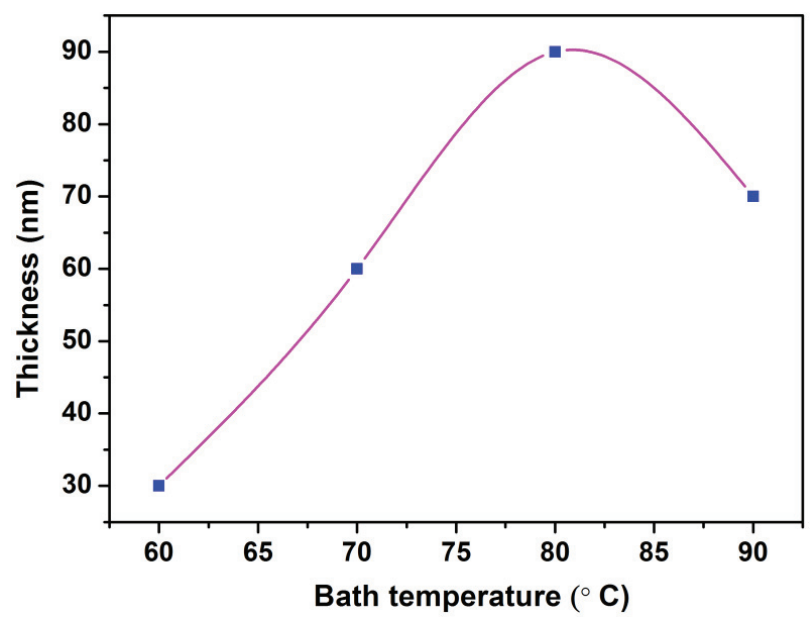

Fig. 2. Variation in the film thickness for different bath temperature 
served that film thickness was increased for bath temperature in the range, $55-75^{\circ} \mathrm{C}$ and then decreased in the range of $75-85^{\circ} \mathrm{C}$ whereas Hariech et al. [4] reported that the thickness was increased for temperature that varied from 55 to $65^{\circ} \mathrm{C}$ and then decreased when the temperature varied in the range, $65-75^{\circ} \mathrm{C}$.

\section{Structure analysis}

Fig. 3 shows the XRD pattern of as-prepared CdS thin films grown at different bath temperatures. The lines in XRD spectra were found to be weak because of the low film thickness of CdS. From the XRD pattern (Fig. 3), it can be seen that CdS thin film prepared at 60 and $70^{\circ} \mathrm{C}$ showed the diffraction peaks at $27.7^{\circ}, 36.2^{\circ}, 41.5^{\circ}, 54.4^{\circ}, 56.9^{\circ}$, and $69.1^{\circ}$, which respectively correspond to the (101), (102), (110), (004), (202), and (210) planes of hexagonal structure of CdS. However, for bath temperatures $>70^{\circ} \mathrm{C}$ (i.e for $80-90^{\circ} \mathrm{C}$ ), XRD patteren of CdS films showed the mixed structures of both hexagonal and $\mathrm{cu}^{-}$ bic. The diffraction peaks observed at $30.1^{\circ}, 54.6^{\circ}$ and $64.6^{\circ}$ correspond to the (200), (222) and (400) planes of cubic structure respectively. All the observed planes were well matched with the JCPDS card nos. 75-1545 and 75-0581 of hexagonal and cubic strcture, respectively.

As seen from Fig. 3, CdS thin film showed hexagonal structure for bath temperatures of 60 and $70{ }^{\circ} \mathrm{C}$, whereas at bath temperatures of 80 and $90^{\circ} \mathrm{C}$, mixed structures of hexagonal and cubic were ob-

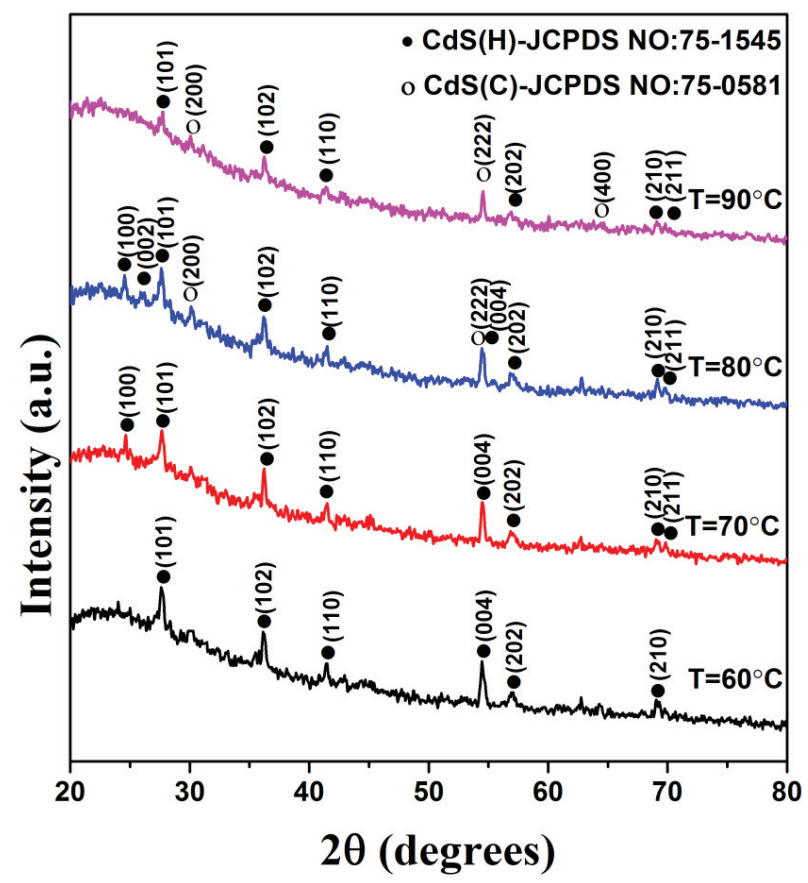

Fig. 3. X-ray diffraction pattern for as prepared CdS thin films at different bath temperatures served. The observed structural changes were due to the following reasons. At lower temperatures, below $70^{\circ} \mathrm{C}$, ion- to-ion deposition process might take place during the growth of the film whereas the cluster-by-cluster process might occur for temperature $>70{ }^{\circ} \mathrm{C}$. Therefore, due to cluster by cluster process at bath temperatures $\geqslant 80^{\circ} \mathrm{C}$, the mixed structures of hexagonal and cubic $\mathrm{CdS}$ was observed. A similar type of structural change during the growth process was also reported by other researchers in the literature [5, 6]. For example, George et al. [7] prepared CdS thin films by CBD using sequential mixing of $25 \mathrm{ml}$ of $0.1 \mathrm{M}$ cadmium nitrate, $20 \mathrm{ml}$ of $1 \mathrm{M}$ sodium citrate, $7.5 \mathrm{ml}$ of $4 \mathrm{M}$ aqueous ammonia, $10 \mathrm{ml}$ of $1 \mathrm{M}$ thiourea and $37.5 \mathrm{ml}$ of deionized water. The deposited CdS films showed hexagonal structure at a bath temperature of $60{ }^{\circ} \mathrm{C}$. On the other hand, Oliva et al. [8] deposited CdS thin films by the chemical bath method using an aqueous solution of cadmium chloride $\left(\mathrm{CdCl}_{2}\right)$, potassium hydroxide $(\mathrm{KOH})$, ammonium nitrate $\mathrm{NH}_{4} \mathrm{NO}_{3}$, and thiourea $\left(\mathrm{CS}\left[\mathrm{NH}_{2}\right]_{2}\right)$. The deposited CdS films showed cubic structure at $75^{\circ} \mathrm{C}$. Lejmi et al. [9] deposited CdS thin films by CBD onto ITO-coated glass substrates using aqueous solutions of $3.5 \cdot 10^{-2} \mathrm{M}\left[\mathrm{Cd}\left(\mathrm{CH}_{3} \mathrm{COO}\right)_{2}\right], 3.5 \cdot 10^{-1} \mathrm{M}\left[\left(\mathrm{NH}_{2}\right)_{2} \mathrm{CS}\right]$, $10^{-1} \mathrm{M}\left(\mathrm{NH}_{4} \mathrm{Ac}\right), 0.3 \mathrm{M}\left(\mathrm{NH}_{4} \mathrm{OH}\right)$ containing $10^{-5} \mathrm{M}$ solutions of HPA or IPA. The deposition of CdS was carried out at $90{ }^{\circ} \mathrm{C}$. XRD results of the deposited films indicated both cubic and hexagonal structures of CdS. The formation of cubic or hexagonal CdS phase depends on many factors including the deposition technique. In chemical bath deposition, the structure of the film depends upon bath temperature, composition and $\mathrm{pH}$ of the solution. In the present case, the rise in bath temperature led to a change in the deposition process, which changes the phase structure of CdS films.

\section{Optical properties}

The absorbance of the material was defined as the logarithmic ratio of the amount of radiation falling on the material to the amount of radiation transmitted through it [10]. Fig. 4 (a) shows the absorbance spectra of CdS thin films prepared at various deposition temperatures. The absorbance of CdS thin films decreased with increase in the bath temperature due to an increase of film thickness as mentioned in section 3.2. (Fig. 2). The deposited CdS thin films showed a sharp absorption edge in the wavelength range of 500-550 nm with temperature. A shift in the absorption edge of CdS towards lower wavelength side was observed with increase of bath temperature due to the quantum size effect. The observed low optical absorption in the visible to near IR region for all films, (except the film pre- 


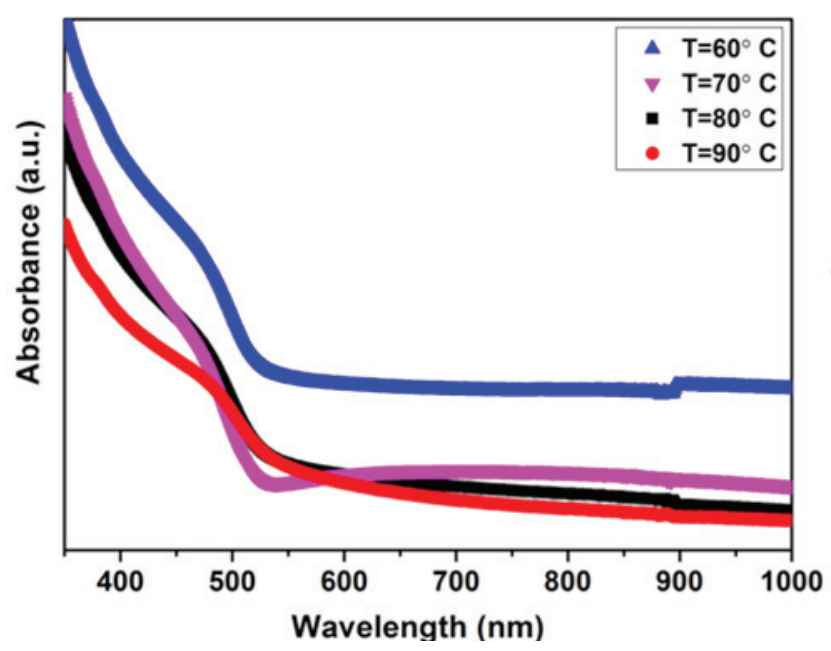

Fig. 4. Absorbance spectra of CdS thin film deposited at different deposition temperatures

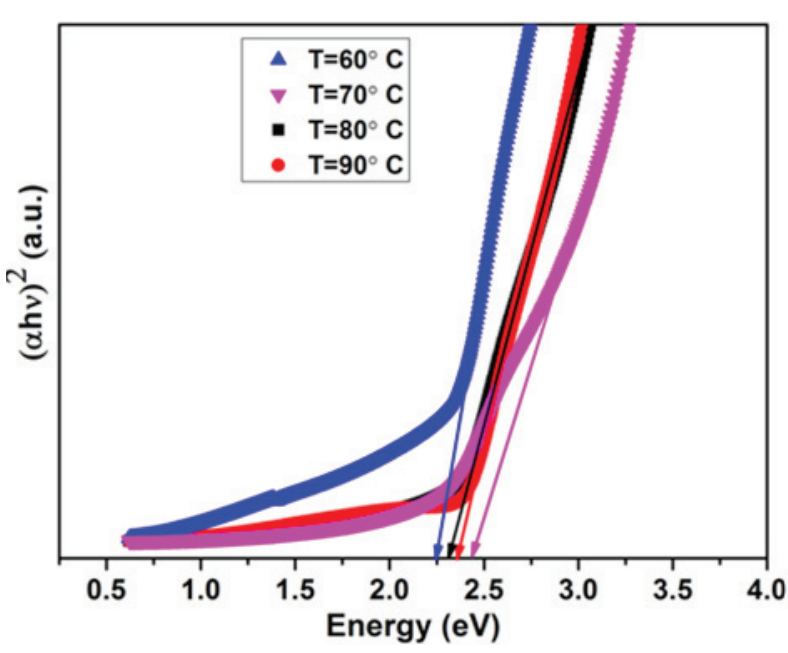

Fig. 5. Plot of $(\alpha h v)^{2}$ versus $h v$ of CdS thin film deposited at different deposition temperatures

curred in the films, which supported the cubic structure. A similar type of trend in the band gap with the change of bath temperature was also reported by others. Kumar et al. [1] prepared CdS nanofilms formed by CBD method for different deposition temperatures that vary in the range $50-90^{\circ} \mathrm{C}$. They observed an increase in the band gap of CdS nanofilms in the bath temperature range between 50 and $70{ }^{\circ} \mathrm{C}$ and thereafter the band gap decreased for the bath temperatures, 80 and $90{ }^{\circ} \mathrm{C}$. Similarly, Sachin et al. [2] prepared CdS thin films by CBD method for different deposition temperatures i.e. 65,75 , and $85^{\circ} \mathrm{C}$. They observed that the band gap of CdS films was increased with bath temperature between 65 to $75^{\circ} \mathrm{C}$ and afterwards it decreased for bath temperatures $>75^{\circ} \mathrm{C}$.

\section{Electrical properties}

Fig. 6 shows the variation in electrical resistivity of CdS thin films with bath temperature. It can be seen from Fig. 6 that electrical resistivity of asprepared CdS thin films was decreased with increase of bath temperature from 60 to $80^{\circ} \mathrm{C}$ and thereafter it increased slightly. The decrease in electrical resistivity of CdS films was due to either interstitial Cd ions or sulfur vacancies existing in the film. These defects might acted as donors thereby resulting in an increase of the carrier concentration. Consequently, the electrical resistivity of CdS was decreased [20]. In addition, the variation in the structure of CdS films with bath temperature was also responsible for the observed variation in the resistivity.

A similar type of trend in the electrical resistivity of CdS films was also reported by Liu et al. 


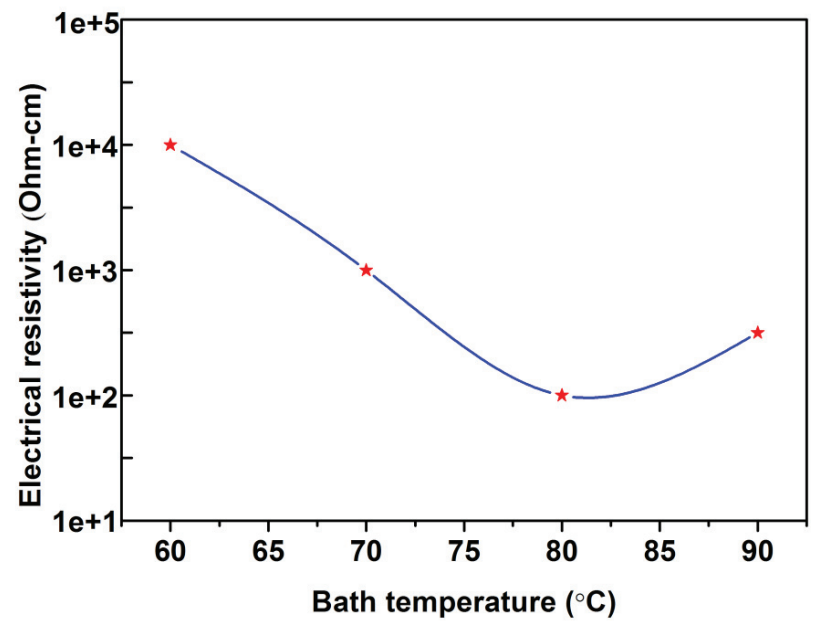

Fig. 6. Dependence of electrical resistivity on bath temperature

[21]. They deposited CdS thin films by CBD using a chemical bath containing $0.03 \mathrm{M}$ cadmium sulfate $\left(\mathrm{CdSO}_{4} \cdot 8 \mathrm{H}_{2} \mathrm{O}\right), 0.1 \mathrm{M}$ thiourea $\left(\mathrm{H}_{2} \mathrm{NCSNH}_{2}\right)$ and $25-$ $28 \%$ ammonium hydroxide $\left(\mathrm{NH}_{4} \mathrm{OH}\right)$. The deposition of CdS thin film was carried out at various temperatures in the range of $55-85{ }^{\circ} \mathrm{C}$. The XRD pattern of CdS film deposited at $55{ }^{\circ} \mathrm{C}$ showed hexagonal structure whereas an increase of bath temperature to $65^{\circ} \mathrm{C}$ promoted the cubic-hexagonal transformation in CdS. Consequently, the measured electrical resistivity of CdS films was decreased from $5 \cdot 10^{5} \Omega$ $\mathrm{cm}$ to $8.5 \cdot 10^{3} \Omega \mathrm{cm}$ with the variation of bath temperature from 55 to $85^{\circ} \mathrm{C}$. Thus, in the present case, the decrease of electrical resistivity in CdS films can be attributed to the concentration of defects present in the films [3, 21-22] as well as the structural changes observed with bath temperature as described earlier in the XRD analysis. The increase of electrical resistivity of $\mathrm{CdS}$ films at $90{ }^{\circ} \mathrm{C}$ was due to the peeling of the film after reaching a limited thickness of $90 \mathrm{~nm}$.

\section{CONCLUSIONS}

The effect of bath temperature on the structural, optical, and electrical properties of CdS thin films formed by CBD process were investigated. It was found that the as-prepared CdS thin films showed hexagonal structure at lower temperature and mixed (hexagonal and cubic) structure at higher temperatures. The band gap energy of CdS films varied in the range of $2.25-2.45 \mathrm{eV}$ with the change of bath temperature. The electrical resistivity considerably decreased with the increase of deposition temperature. The main reason for these changes in structural, optical, and electrical properties was attributed to change in the growth mechanism of CdS thin films with deposition temperature.

\section{SOURCE OF FINANCING}

Work was performed with assistance of the Ministry of Education and Science of the Russian Federation, number of agreement 14.613.21.0065 (the unique identificator of the project RFMEF161317X0065).

The authors also wish to acknowledge the financial support funded by “DEPARTMENT OF SCIENCE \& TECHNOLOGY, Ministry of Science \& Technology, Government of India” (No. DST/INT/RMES/P11/2016) in association with "Russian Ministry of Education and Sciences (RMES)" Government of Russia.

\section{ACKNOWLEDGMENTS}

The equipment of Analytical Core Facilities Centre of Institute of Problems of Chemical Physics of RAS was used during the study.

\section{CONFLICT OF INTERESTS}

On behalf of all authors, the corresponding author states that there is no conflict of interest.

\section{REFERENCES}

1. Kumar S., Sharma P., Sharma V. CdS nanofilms: effect of deposition temperature on morphology and optical band gap. Physica Scripta, 2013, v. 88(4), p. 045603. DOI: https://doi.org/10.1088/00318949/88/04/045603

2. Rondiyaa S., Rokadea A., Gabhalea B., Pandharkara S., Chaudharia M., Dateb A., et al. Effect of bath temperature on optical and morphology properties of CdS thin films grown by chemical bath deposition. Energy Procedia, 2017, v. 110, pp. 202-209. DOI: https://doi.org/10.1016/j.egypro.2017.03.128

3. Fangyang Liu, Yanqing Lai, Jun Liu, Bo Wang, Sanshuang Kuang, Zhian Zhang, et al. Characterization of chemical bath deposited CdS thin films at different deposition temperature. J. Alloys Compd., 2010, v. 493(1-2), pp. 305-308.DOI: https://doi.org/10.1016/ j.jallcom.2009.12.088

4. Hariech S., Aida M. S., Bougdira J., Belmahi M., Medjahdi G., Genuve D., et al. Cadmium sulfide thin films growth by chemical bath deposition. J. Semicond., 2018, v. 39(3), p. 034004.DOI: https://doi.org/10.1088/ 1674-4926/39/3/034004

5. Mane R. S., Lokhande C. D. Chemical deposition method for metal chalcogenide thin films. J. Mater. Chem. Phys., 2000, v. 65(1), p. 1-31. DOI: https://doi. org/10.1016/s0254-0584(00)00217-0

6. Hodes G. Chemical solution deposition of semiconductor films. Monograph, Boca Raton, CRC Press, 2002, 388 p. DOI: https://doi.org/10.1201/9780 203909096

7. George P. J., Sanchez-Juarez A., Nair P. K. Modification of electrical, optical and crystalline properties 
of chemically deposited CdS films by thermal diffusion of indium and tin. Semicond. Sci. Technol., 1996, v. 11(7), pp. 1090-1095. DOI: https://doi.org/10.1088/ 0268-1242/11/7/021

8. Oliva A. I., Solis-Canto O., Castro-Rodriguez R., Quintana P. Formation of the band gap energy on CdS thin films growth by two different techniques Thin Solid Films, 2001, v. 391(1), pp. 28-35. DOI: https://doi. org/10.1016/s0040-6090(01)00830-6

9. Lejmi N., Savadogo O. The effect of heteropolyacids and isopolyacids on the properties of chemically bath deposited CdS thin films. Sol. Energy Mater. Sol. Cells, 2001, v. 70(1), pp. 71-83. DOI: https:// doi.org/10.1016/s0927-0248(00)00412-8

10. Gray D.E. American Institute of Physics Handbook. 3rd Edition, McGraw-Hill, New York, pp. 4-58.

11. Ravi Kant Choubey, Dipti Desai, Kale S. N., Sunil Kumar. Effect of annealing treatment and deposition temperature on CdS thin films for CIGS solar cells applications. J. Mater. Sci: Mater. in Elec., 2016, v. 27(8), pp. 7890-7898. DOI: https://doi. org/10.1007/s10854-016-4780-2

12. Lo Y. S., Choubey R. K., Yu W. C., Hsu W. T., Lan C. W. Shallow bath chemical deposition of CdS thin film. Thin Solid Films, 2011, v. 520(1), pp. 217-223. DOI: https://doi.org/10.1016/j.tsf.2011.07.035

13. Cortes A., Gomez H., Marotti R. E., Riveros G., Dalchiele E. A. Grain size dependence of the bandgap in chemical bath deposited CdS thin films. Sol. Energy Mater. Sol. Cells, 2004, v. 82(1-2), pp. 21-34. DOI: https://doi.org/10.1016/j.solmat.2004.01.002

14. Ahmad F. R., Yakimov A., Davis R. J., Her J. H., Cournoyer J. R., Ayensu N. M. Effect of thermal annealing on the properties of cadmium sulfide deposited via chemical bath deposition. Thin Solid Films, 2013, v. 535, pp. 166-170. DOI: https://doi.org/10.1016/j. tsf.2012.10.085

15. Rakhshani A. E., Al-Azab A. S. Characterization of CdS films prepared by chemical-bath deposition. J. Phys. Condens. Matter., 2000, v. 12, pp. 8745-8756. DOI: https://doi.org/10.1088/0953-8984/12/40/316

16. Al Kuhaimi S. A.// Vacuum, 1998, v. 51, pp. 34955.

17. Zelaya-Angel O., Alvarado-Gil J. J., LozadaMorales R., Vargas H., Ferreira da Silva A. Band-gap shift in CdS semiconductor by photoacoustic spectroscopy: Evidence of a cubic to hexagonal lattice transition. Appl. Phys. Lett., 1994, v. 64(3), pp. 291-293. DOI: https://doi.org/10.1063/1.111184

18. Chopra K. L. Thin Film Phenomena. McGrawHill, New York, 1969, 266 p.

19. Pattabi M., Uchil J. Synthesis of cadmium sulphide nanoparticles. Sol. Energy Mater. Sol. Cells, 2000, v. 63(4), pp. 309-314. DOI: https://doi.org/10.1016/ s0927-0248(00)00050-7

20. Hani Khallaf, Isaiah O. Oladeji, Guangyu Chai, Lee Chow. Characterization of CdS thin films grown by chemical bath deposition using four different cadmium sources. Thin Solid Films, 2008, v. 516(21), pp. 73067312. DOI: https://doi.org/10.1016/j.tsf.2008.01.004

21. Sasikala G., Thilakan P., Subramanian C. Modification in the chemical bath deposition apparatus, growth and characterization of CdS semiconducting thin films for photovoltaic applications. Sol. Energy Mater. Sol. Cells, 2000, v. 62(3), pp. 275-293. DOI: https://doi.org/10.1016/s0927-0248(99)00170-1

22. Toma A., Vigil O., Alvarado-Gil J. J., LozadaMorales R., Zelaya-Angel O., Vargas H., et al. Influence of thermal annealings in different atmospheres on the band-gap shift and resistivity of CdS thin films. J. Appl. Phys., 1995, v. 78(4), p. 2204-2207. DOI: https://doi. org/10.1063/1.360136 


\title{
Влияние температуры химического осаждения на структурные, оптические и электрические свойства тонких пленок сульфида кадмия
}

\section{(c) 2019 М. В. Гапанович ${ }^{1}$, Н. А. Тихонина ${ }^{1}$, Т. С. Коковина ${ }^{2}$, Д. Н. Варесеев ${ }^{1,2}$, В. В. Ракитин ${ }^{1}$,} M. Reddivari ${ }^{3}$, P. Babu ${ }^{3}$, K.T . Ramakrishna Reddy ${ }^{3}$, Г. Ф. Новиков ${ }^{\boxplus 1,2}$

${ }^{1}$ Институт проблем химической физики Российской академии наук nр. академика Семенова, д. 1, 142432 Черноголовка, Московская обл., Российская Федерация

${ }^{2}$ Московский государственный университет им. М.В. Ломоносова, факультет фундаментальной физико-химической инженерии

ГСП-1, Ленинские горы, д. 1, 119991 Москва, Российская Федерация

${ }^{3}$ S.V. University, Solar Photovoltaic Laboratory, Department of Physics Andhra Pradesh, 517502 Tirupati, India

\begin{abstract}
Аннотация. Изучено влияние температуры синтеза $\left(60-90^{\circ} \mathrm{C}\right)$ на структурные, оптические и электрические свойства тонких пленок $\mathrm{CdS}$, осажденных методом химического осаждения (CBD) при постоянной концентрации прекурсора и времени осаждения. Из рентгеноструктурного анализа было установлено, что структура тонких пленок CdS изменяется в зависимости от температуры. При более низкой температуре преобладала шестиугольная структура, а при высокой температуре - кубическая. По данным спектроскопии в области УФ и видимого диапазона была рассчитана ширина запрещенной зоны конечных тонких пленок CdS, и установлено, что она уменьшается с повышением температуры. Удельное сопротивление тонких пленок CdS также уменьшалось с увеличением температуры синтеза.
\end{abstract}

Ключевые слова: сульфид кадмия, метод химического осаждения (CBD), температурный эффект, структурные изменения, механизм роста, электрические свойства.

Гапанович Михаил Вячеславович - к. х. н., с. н. с., Институт проблем химической физики РАН, Черноголовка, Московская область, Российская Федерация; e-mail: gmw@icp.ac.ru. ORCID iD: https://orcid.org/0000-0002-9109-6532.

Тихонина Наталья Александровна - к. х. н., ведущий инженер, Институт проблем химической физики РАН, Черноголовка, Московская область, Российская Федерация; e-mail: evgeniar@mail.ru.

Коконина Татьяна С. - студентка, Московский государственный университет им. М.В. Ломоносова, факультет фундаментальной физико-химической инженерии, Москва, Российская Федерация.
Mikhail V. Gapanovich - Cand. Sci. (Chem.), Senior Researcher, Institute of Problems of Chemical Physics of Russian Academy of Sciences, Chernogolovka, Moscow Region, Russian Federation; e-mail: gmw@icp.ac.ru.ORCID iD: https://orcid.org/00000002-9109-6532.

Natalia A. Tikhonina - Cand. Sci. (Chem.), Senior Engineer, Institute of Problems of Chemical Physics of Russian Academy of Sciences, Chernogolovka, Moscow Region, Russian Federation; e-mail: evgenia-r@mail.ru.

Tatiana S Kokovina - student, Lomonosov Moscow State University, Faculty of Fundamental Physicochemical Engineering, Moscow, Russian Federation.

Новиков Геннадий Федорович, e-mail: gfnovikov@gmail.com 
Варесеев Дмитрий Н. - студент, инженер, Институт проблем химической физики РАН, Черноголовка, Московская область; Московский государственный университет им. М.В. Ломоносова, факультет фундаментальной физико-химической инженерии, Москва, Российская Федерация.

Ракитин Владимир Валерьевич - к. х. н., н. с., Институт проблем химической физики РАН, Черноголовка, Московская область, Российская Федерация; e-mail: domi-tyan@yandex.ru. ORCID ID: https://orcid.org/0000-0001-6582-5212.

Muniramaiah Reddivari - М. н. с. (физика), солнечная фотоэлектрическая лаборатория, физический факультет, университет Sri Venkateswara, Тирупати, штат Андхра-Прадеш, Индия; e-mail: r.muniram1995@gmail.com.ORCID iD: https://orcid.org/0000-0003-0903-3493.

Babu Pejjai - Ph.D, н. с., солнечная фотоэлектрическая лаборатория, физический факультет, университет Sri Venkateswara, Тирупати, штат Андхра-Прадеш, Индия; e-mail: pdmj.babu@ gmail.com. ORCID iD: https://orcid.org/0000-00015768-9433.

Tulasi Ramakrishna Reddy Kotte - Ph.D, професcop, заведующий солнечной фотоэлектрической лабораторией, физический факультет, университет Sri Venkateswara, Тирупати, штат Андхра-Прадеш, Индия; e-mail: ktrkreddy@gmail. com. ORCID iD: https://orcid.org/0000-0002-34576505.

Новиков Геннадий Фёдорович - д. ф.-м. н., профессор, заведующий лабораторией, Институт проблем химической физики РАН; Московский государственный университет им. М.В. Ломоносова, факультет фундаментальной физикохимической инженерии, Москва, Российская Федерация; e-mail:ngf@icp.ac.ru. ORCID iD: https:// orcid.org/0000-0002-5458-8263.
Dmitry N. Varseev - student, Engineer, Institute of Problems of Chemical Physics of Russian Academy of Sciences, Chernogolovka, Moscow Region; Lomonosov Moscow State University, Faculty of Fundamental Physicochemical Engineering, Moscow, Russian Federation.

Vladimir V. Rakitin - Cand. Sci. (Chem.), Researcher, Institute of Problems of Chemical Physics of Russian Academy of Sciences, Chernogolovka, Moscow Region, Russian Federation; e-mail: domityan@yandex.ru.ORCID iD: https://orcid.org/00000001-6582-5212.

Muniramaiah Reddivari - Junior Research Fellow (Phys.), Solar Photovoltaic Laboratory, Department of Physics, Sri Venkateswara University, Tirupati, Andhra Pradesh, India; e-mail: r.muniram1995@ gmail.com. ORCID iD: https://orcid.org/0000-00030903-3493.

Babu Pejjai - Ph.D, Associate Research, Solar Photovoltaic Laboratory, Department of Physics, Sri Venkateswara University, Tirupati, Andhra Pradesh, India; e-mail:pdmj.babu@gmail.com. ORCID iD: https://orcid.org/0000-0001-5768-9433.

Tulasi Ramakrishna Reddy Kotte - Ph.D (Phys.), Professor, Head of Solar Photovoltaic Laboratory, Department of Physics, Sri Venkateswara University, Tirupati, Andhra Pradesh, India; e-mail: ktrkreddy@gmail.com. ORCID iD: https://orcid.org/00000002-3457-6505.

Gennady F. Novikov - Dr. Sci.(Phys.- Math.), Full Professor, Head of Laboratory, Institute of Problems of Chemical Physics of Russian Academy of Sciences, Chernogolovka, Moscow Region; Lomonosov Moscow State University, Faculty of Fundamental Physicochemical Engineering, Moscow, Russian Federation; e-mail: gmw@icp.ac.ru. ORCID iD: https://orcid.org/0000-0002-5458-8263. 